\title{
Correlational Investigation of Indonesian EFL Learners' Critical Thinking, and Grammar Mastery with Their Reading Comprehension Achievement
}

\author{
Alek, Estetika Handayani \\ Syarif Hidayatullah State Islamic University Jakarta, Jl. Ir. H. Djuanda 95, Ciputat, Indonesia \\ Corresponding e-mail: $\underline{\text { alek@uinjkt.ac.id }}$
}

\begin{abstract}
Critical thinking and grammar mastery play a prominent role in fostering students' reading comprehension skill. Reading comprehension is a prominent aspects to develop other English skills. The present study was to investigate the relationship Indonesian learners' critical thinking with their reading comprehension achievement. The participants were 53 first year of university students which majoring in English. The sample of the recent study was chosen through simple random sampling. The data were analyzed by using Pearsons' correlation calculation. The finding of the study indicated that: firstly, the relationship between critical thinking and reading comprehension achievement was categorized moderate interpretation. Secondly, the relationship between grammar mastery and reading comprehension was in moderate categorized. Based on the results above, it can be summed up that among variables show a significant correlation between critical thinking and reading comprehension; grammar mastery with reading comprehension achievement. The other researchers should take a consideration to continue deeply, widely, comprehensively to obtain a wholeness and completeness. Last but not least. The study has implications for course designers, teachers, and students.
\end{abstract}

Keywords: Reading Comprehension Achievement, Critical Thinking, Grammar Mastery

\section{INTRODUCTION}

There are many researchers have investigated that focused on reading comprehension at both school and university stages of education (Ibrahim, et al. 2016; Abdelaal, 2014; Jiang, 2015; Young, 2014; and Sabet, Masoud Khalili; Kiaee, Marjan Mesbah, 2016). Based on their investigation results, students' reading comprehension achievement can be affected by reading strategy and critical thinking.

Critical thinking and grammar mastery give much contribution in fostering students' reading comprehension skill. Critical thinking has a significant role in higher education and the professions. It can be considered as a core of higher education and as a fund (Moon, 2008). She believes that if critical thinking is clearly expressed in higher education, then students who are achieving those levels of qualification will be critical thinkers.
Reading comprehension is one of prominent aspects to develop other English skills. English as a foreign language is used for non-native English speakers learning English in a country where English is not commonly spoken. English Language Learners, and more recently English Learners, have been used instead, and the students' home language and cultures are considered important.

Language has four main skills; they are listening, speaking, reading, and writing. Related to this respect, in order to have a good skill in English reading comprehension, there may be many aspects that can influences EFL learners in developing and mastering the language. That is why the researchers choose one of the English skill and its sub-skill to be investigated on this research.

In the process of reading, students receive information through the eyes, discriminate letter shapes, associate the letter with language and 
associate the text with meaning. Reading is a complex cognitive process of decoding symbols in order to construct or derive meaning reading comprehension. It is a means of language acquisition, of communication, and of sharing information and ideas. . Reading usually means dealing with language messages in written or printed form, it involves processing language messages, hence knowledge of language (Liu, 2010, p. 01).

Critical thinking is the way which uses the cognitive skills or strategies that increase the probability of a desirable outcome (Halpern, 1999). Referring to Halpern's idea, particularly, for the students of English department on higher education level should have a good critical thinking, especially to support their reading comprehension.

Furthermore student with critical thinking skills are the essential for higher order problem-solving thinking. The lists of critical thinking skills, characteristics, and aspects identified by experts to indicate they type of thinking and approach to life (Vaseghi, 2012, p. 403).

English students in university need other supporting factors that can influence their achievement in reading, it is the common problem that faced by students in learning grammar. Grammar was a component of English sub-skill; student must have a high level in understanding of grammatical rules in context. The recent study is to investigate and analyze the relationship between critical thinking and reading comprehension. By its development processes, the nature and understanding the definition in critical thinking has been discussed include the schema theory as a rational premise for the connection between this correlation.

\section{METHOD}

This research was a quantitative research method. According to Kerlinger (in Sugiyono, 2013, p. 34) says that "Survey research studies large and small population (or universes) by selecting and studying samples chosen from population to discover the relative incident, distribution, and interrelations of sociological and psychological variables." The correlational study here was meant that researchers intended to know the relationship between critical thinking, grammar mastery with their reading comprehension achievement. The critical thinking and grammar mastery could affect the achievement in reading comprehension. These relationship, if they were positively found, would make ease to comprehend the reading.

From the correlations, the researchers determined the correlation together without seeing the higher correlation score. This research used correlational study method in which the variables were correlated each other. It is designed to know whether there is any significant relationship among these variables.

\subsection{Research Instrument}

The instruments were used in the research. The first is the instrument which was used to measure the student reading comprehension; the second is a test about grammar. Both reading comprehension and grammar tests were tested to ensure both validity and reliability. Meanwhile the instrument of critical thinking was double checked by the experts in order to obtain a certainty about eligibility and appropriateness of the instrument (Creswell, 2008, p. 123).

\section{FINDING}

\subsection{The relationship between critical thinking and reading comprehension achievement}

In obtaining the result of this calculation, it was used a statistical correlation calculation using Pearson correlation testing.

Table 1

Pearsons' Correlation Result

\begin{tabular}{|c|c|c|c|c|}
\hline & & $\begin{array}{l}\text { Read } \\
\text { Comp }\end{array}$ & $\begin{array}{l}\text { Crit } \\
\text { Think }\end{array}$ & $\begin{array}{l}\text { Gram } \\
\text { Mast }\end{array}$ \\
\hline \multirow{3}{*}{$\begin{array}{l}\text { Read } \\
\text { Comp }\end{array}$} & Pearson & 1 & $.495^{* *}$ & $.437^{* *}$ \\
\hline & $\begin{array}{l}\text { Sig. (2- } \\
\text { tailed) }\end{array}$ & & .000 & .001 \\
\hline & $\mathrm{N}$ & 53 & 53 & 53 \\
\hline Critical & Pearson & & & \\
\hline \multirow[t]{3}{*}{ Thinking } & $\begin{array}{l}\text { Correlat } \\
\text { ion }\end{array}$ & $.495^{* *}$ & 1 & .213 \\
\hline & $\begin{array}{l}\text { Sig. (2- } \\
\text { tailed) }\end{array}$ & .000 & & .126 \\
\hline & $\mathrm{N}$ & 53 & 53 & 53 \\
\hline Gram & Pearson & & & \\
\hline \multirow[t]{3}{*}{ Mastery } & $\begin{array}{l}\text { Correlat } \\
\text { ion }\end{array}$ & $.437^{* *}$ & .213 & 1 \\
\hline & $\begin{array}{l}\text { Sig. (2- } \\
\text { tailed) }\end{array}$ & .001 & .126 & \\
\hline & $\mathrm{N}$ & 53 & 53 & 53 \\
\hline
\end{tabular}

**. Correlation is significant at the 0.01 level (2-tailed). 
Based on the result of statistical calculation as seen in Table 1 above, it shows that the relationship between critical thinking and reading comprehension achievement was 0.495 . it means that there is a close significant relationship. The reason is the score 0.495 was higher than $r$ table $\mathrm{N}=26$ participants in level of significance score 0.270 . It means that the score was confirmed between critical thinking and reading comprehension achievement.

Based on the correlation coefficient score 0.495 of the relationship between critical thinking and reading comprehension achievement. It can be matched on the Table 1 above, the correlation coefficient strength was in "moderate" interpretation because the score was 0.495 . It can be stated that critical thinking was influenced enough to achieve comprehension in reading. It would be contributing in reading and more criticize in thinking.

It can be concluded that the relationship between critical thinking and reading comprehension achievement is significant because the 0.000 is lower than 0.05 . The answer from the hypothesis 1 is Hi was accepted and Ho is rejected. The statement for this hypothesis is "there is a significant relationship between critical thinking and reading comprehension achievement."

\subsection{The relationship between grammar mastery and reading comprehension achievement}

Based on the calculation result as seen in the Table 1 above, in reading comprehension row and grammar mastery column. The score in relationship between grammar mastery and reading comprehension achievement as the second hypothesis was 0.437 , it means that there is a relationship. The reason is the score 0.437 was higher than $r$ table $\mathrm{N}=53$ participants in level of significance score 0.270 . It means that the score was confirmed between grammar mastery and reading comprehension achievement.

The next stage is would like to know the closeness of the relationship between grammar mastery and reading comprehension achievement. The following simple regression calculation which is operated to get the closeness which means contribution of the relationship among this these variable, and the result confirmed clearly about the closeness significance among them.

\subsection{The co-relationship among critical thinking, grammar mastery and reading comprehension achievement}

This final hypothesis clearly informed that in research is directed to the first option. It was calculated by using a multiple correlation and regression calculation statistically. The result shows a significant relationship. it can be seen in data in the Table 1 above which calculated and then the F score had to be found out. Before paying attention to the $\mathrm{F}$ column on the Table 1 above, let us find the F table from the degree of freedom $(\mathrm{df})$. As seen from the df score, it was from df 1 and df 2 . The df 1 is the number of dependent variable and independent variable minus 1 . After that, in the df 2 was the number of participants minus the number of dependent and independent variable. The result of $\mathrm{df}$ 1 was three minus one is equal to two $(3-1=2)$, for the result of df 2 was fifty three minus three is equal to twenty three $(53-3=50)$.

\section{DISCUSSION}

Based on the result show that critical thinking and reading comprehension achievement from Pearson's correlation established as having relationship with the score 0.495 was higher than $r$ table 0.270 . So the correlation was in "moderate" interpretation based on the correlation coefficient strength Table $1(0.300$ to 0.500$)$. Meanwhile, grammar mastery and reading comprehension achievement which has been calculated by operating the Pearsons' correlation from the multiple correlation and regression calculation. Furthermore the relationship among three variables $\mathrm{X} 1, \mathrm{X} 2$ and $\mathrm{Y}$. It means that the independent variables were critical thinking and grammar mastery to be correlated to the dependent variable was reading comprehension achievement.

As long as there is relationship among these variables, students be able to learn more to get better in grammar mastery and they could be increased their skill in thinking when reading and their critical in analyzing. As discussion result, the relationship was in "moderate" criteria in critical thinking toward reading comprehension. Then, also has the same criteria in grammar mastery toward reading comprehension. For the co-relationship of two variables toward reading comprehension made the relationship was in "strong" criteria. But the students still need harder to learn several aspects which can 
be influence to maximize the result in reading comprehension achievement.

\section{CONCLUSIONS}

Based on the finding and discussion, it can be concluded that: Firstly, there is relationship between critical thinking and reading comprehension achievement was categorized moderate interpretation. Secondly, the relationship between grammar mastery and reading comprehension was in moderate categorized; and Lastly, the relationship between critical thinking, grammar mastery and reading comprehension achievement as together were strong correlated. Based on the results above, it would be summed up that among variables show a significant correlation between critical thinking and reading comprehension; grammar mastery with reading comprehension achievement.

\section{REFERENCES}

Alderson, J. C. (2000). Assessing reading, Cambridge. University Press.

Creswell, J. (2008). Educational research: Planning, conducting, and evaluating quantitative and qualitative research, New Jersey: Pearson Merrill Prentice Hall.

Ennis, R. H. (2001). The critical thinking assessment. theory into practice, 32(3).

Ennis, R.H. (2011). The nature of critical thinking; an outline of critical thinking dispositions \& abilities, University of Illinois.

Vaseghi, R., Gholami, R., Barjesteh, H., (2012). Critical thinking: an influential factor in developing english reading performance, World Science Publisher. United State. Ass, 2(1).

F. (2000). A Vocabulary program to complement and bolsters a middle-grade comprehension Program. In B. M. Taylor, M. F. Graves, \& P. Van den broek (eds.), Reading For Meaning: Fostering Comprehension in the middle grades. Newark, DE: International Reading Association.

Halpern, D. F. (1999). Teaching for critical thinking: Helping college students develop the skills and dispositions of a critical thinker. New Directions for Teaching and Learning, 80, 6974

Halpern, D. F. (2001). Assessing the effectiveness of critical thinking instruction. The Journal of General Education, 50(4).

Harmer, J. (2001). The Practice of English Language Teaching; Longman Hands Book for
Language Teachers. Longman: Addison Wesley Publishing Company.

He, T. (2008). Reading for Different Goals: The interplay of EFL College Student's Multiple Goals, Strategy Use and Reading Comprehension, Journal of Research in Reading, 31(2).

Liu, F. (2010). A short analysis of the nature of reading, Qingdao University Technology, 3(03).

Kolln, M., Funk, R. (2009). Understanding and Using English Grammar, $9^{\text {th }}$ (e.d). Pearson.

$\mathrm{Ku}$, K. Y. (2009). Assessing students' critical thinking performance: urging for measurements using multi-response format. thinking skills and creativity.

Martino, N.L. \& Hoffman, P.R. (2002). an investigation of reading and language abilities of college freshmen. Journal of Research in Reading.

Moje, E.B., Overby, M., Tysvaer, N, and Morris, K. (2008). The complex word of adolescent literacy: myths, motivations, and mysteries, Harvard Educational Review, 78.

Moon, J. (2008). Critical thinking: An exploration of theory and practice, UK: Library of Congress.

Moseley, D., Baumfield, V., Elliott, J., Gregson, M., Higgins, S., Miller, J., \& Newton, D. P. (2005). Frameworks for Thinking: A Handbook for Teaching and Learning. Cambridge: Cambridge University Press.

Mulnix, J. W. (2010). Thinking critically about critical thinking. educational philosophy \& theory.

Pithers, R. T., \& Soden, R. (2000). Critical thinking in education: A review. Educational research, 42(3).

Sugiyono. (2013). Cara mudah menyusun skripsi, thesis, dan disertasi. Bandung. Alfabeta.

Pretorius, E.J. (2002). Reading and applied linguistics: a defining silence?, South African Linguistics and Applied Language Studies.

Purpura, J.E. (2004). Assessing grammar. Newyork: Cambridge University Press. 